\title{
Large protein as a potential target for use in rabies diagnostics
}

\author{
I. S. SANTOS KATZ1 ${ }^{1}$, M. H. DIAS ${ }^{2}$, I. F. LIMA $^{2}$, L. B. CHAVES ${ }^{1}$, O. G. RIBEIRO ${ }^{3}$, K. C. SCHEFFER ${ }^{1}$, L. K. IWAI ${ }^{2}$ \\ ${ }^{1}$ Laboratório de Diagnóstico da Raiva, Instituto Pasteur of São Paulo, Ave. Paulista, 393, São Paulo, Brazil; ${ }^{2}$ Laboratório Especial de \\ Toxinologia Aplicada (LETA), Center of Toxins, Immune-Response and Cell Signaling (CeTICS), Instituto Butantan, São Paulo, \\ Brazil; ${ }^{3}$ Laboratório de Imunogenética, Instituto Butantan, São Paulo, Brazil
}

Received August 30, 2016; revised November 11, 2016; accepted July 15, 2017

\begin{abstract}
Summary. - Rabies is a zoonotic viral disease that remains a serious threat to public health worldwide. The rabies lyssavirus (RABV) genome encodes five structural proteins, multifunctional and significant for pathogenicity. The large protein $(\mathrm{L})$ presents well-conserved genomic regions, which may be a good alternative to generate informative datasets for development of new methods for rabies diagnosis. This paper describes the development of a technique for the identification of L protein in several RABV strains from different hosts, demonstrating that MS-based proteomics is a potential method for antigen identification and a good alternative for rabies diagnosis.
\end{abstract}

Keywords: rabies virus; large protein; street virus; target; mass spectrometry; proteomics

\section{Introduction}

Rabies is an acute, fatal encephalitis caused by rabies lyssavirus (RABV) of the Rhabdoviridae family, the genus Lyssavirus (King et al., 2012). It is one of the most important zoonoses that affect the central nervous system (CNS) of mammals, especially in the orders Carnivora and Chiroptera (Rupprecht et al., 2002).

The RABV genome consists of one RNA molecule of approximately $12 \mathrm{~kb}$ that encodes five structural proteins: the nucleoprotein $(\mathrm{N})$, phosphoprotein $(\mathrm{P})$, RNA-dependent RNA polymerase (L, also termed as RNA-dependent RNA polymerase), glycoprotein (G), and the matrix protein (M) (Wunner et al., 1988). The five mRNAs encode proteins of approximately 450 (N-mRNA), 297 (P-mRNA), 202 (M-mRNA), 524 (G-mRNA) and 2142 (L-mRNA) amino acids (Wunner et al., 1988). The P, L and $\mathrm{N}$ are associated

E-mail: ianasuly@gmail.com; phone: +551198249-6010.

Abbreviations: $\mathrm{G}=$ glycoprotein; $\mathrm{L}=$ large protein or RNAdependent RNA polymerase; $\mathrm{M}=$ matrix protein; $\mathrm{MS}=$ mass spectrometry; $\mathrm{N}$ = nucleoprotein; OIE = World Organization for Animal Health; $\mathrm{P}$ = phosphoprotein; $\mathrm{RABV}$ = rabies lyssavirus; RT-PCR = reverse transcription PCR; SRM = selected reaction monitoring; $\mathrm{WHO}=$ World Health Organization with helical ribonucleoprotein (RNP) complex and play critical role in virus replication and transcription, and also in induction of cellular immune responses (Wunner et al., 1988; Tollis et al., 1991). Moreover, a recent study showed that $\mathrm{L}$ protein plays important roles in pathogenicity and immune evasion during RABV infection, where recombinant RABV with mutations in the $\mathrm{L}$ protein are more sensitive to type I interferon inhibitory activity (Tian et al., 2015). G protein induces neutralizing antibodies against RABV and is also important for the transsynaptic spread of the virus between neurons (Wunner et al., 1988; Etessami et al., 2000).

The World Health Organization (WHO) and the World Organization for Animal Health (OIE) recommend as gold standard for the diagnosis of rabies the direct fluorescent antibody test, rapid tissue culture infection test and mouse inoculation test (OIE, 2012; Yousaf et al., 2012; WHO, 2016). However, these conventional techniques have limited success for antemortem diagnosis in human rabies. Early and precise rabies diagnosis is crucial because a delay in diagnosis can result in dissemination of the disease to contacts and unnecessary postexposure treatment (Madhusudana and Sukumaran, 2008; Gadre et al., 2010; Yousaf et al., 2012). Furthermore, early diagnosis during the acute phase of the disease can help in patient care in order to increase the survival rate. 
These challenges in the rabies diagnosis have stimulated the use of new techniques, which are more sensitive and precise for detection and characterization of the RABV. Recent advances in diagnostic methods based on the characterization of RABV nucleoprotein and glycoprotein, such as phylogeographic analysis, reverse transcription polymerase chain reaction (RT-PCR) and immunohistochemical test, have been used to complement the conventional diagnostic approaches (Silva et al., 2013). These techniques for the diagnosis of rabies are mainly based on detection of the nucleoprotein, nevertheless, RABV polymerase L protein has equivalent conservation degree as the nucleoprotein among the RABV (Le Mercier et al., 1997), but it is little studied for rabies diagnosis (Dacheux et al., 2016).

Mass spectrometry (MS)-based proteomic studies with RABV have been used to elucidate pathogenic and immunogenic properties of the virus, as well as for identification of new biomarkers (Thanomsridetchai et al., 2011; Venugopal et al., 2013; Mehta et al., 2016). Moreover, the identification of microorganisms, such as adenovirus and coronavirus, by MS has been explored, scanning and characterizing intact proteins by amino acid sequencing using peptide mass fingerprinting. Ying and collaborators have identified three structural proteins of severe acute respiratory syndrome coronavirus (SARS-CoV) isolated from infected Vero E6 cells using protein separation by sodium dodecyl sulfatepolyacrylamide gel electrophoresis (SDS-PAGE) and peptide sequencing obtained through analysis of mass spectra and MS/MS fragmentation patterns (Ying et al., 2004). In addition, Zeng and collaborators have predicted four structural proteins of SARS-CoV using one- and two-dimensional gel electrophoresis followed by ESI-MS/MS identification (Zeng et al., 2004). In a more recent work performed by
Benevento and collaborators, a technique known as shotgun proteomics was used to characterize the adenovirus HAdVAd5F35 and select the best peptide candidates for selected downstream reaction-monitoring (SRM) assays in complex samples (Benevento et al., 2014). These studies demonstrate that the identification of viral peptides by MS could be effectively employed as a diagnostic method for an accurate and sensitive screening of virus-infected cells.

In this study, we used the MS-based proteomics for identification of rabies peptides. This method allowed us to identify RABV L protein as a new target that can be incorporated in the RABV diagnosis and we demonstrated that MS-based proteomics is a good alternative for RABV diagnosis.

\section{Materials and Methods}

$R A B V$ strain and virus replication. Wild RABV strains were obtained from brain of different hosts (Table 1) and propagated in murine neuroblastoma cells (N2a) growing in MEM supplemented with $10 \%$ fetal bovine serum, $3 \%$ of gentamicin and $3 \%$ nonessential amino acids (Castilho et al., 2007). To determine virus titer, N2a cells in 96-well plates (Corning/Costar) were infected with serial 10-fold virus dilutions as described previously (Hierholzer and Killington, 1996). All samples were antigenic, and molecular characterization was performed as previously described (Diaz et al., 1994; Orciari et al., 2001). In all reactions, the positive control was the fixed "Challenge Virus Standard" strain (CVS-31) and the negative control was the complete medium alone.

Solubilization of $R A B V$. After virus replication, the supernatant was clarified by centrifugation at $12,000 \mathrm{x}$ g for $15 \mathrm{~min}$ at $4^{\circ} \mathrm{C}$. A buffered detergent solution $(50 \mathrm{mmol} / \mathrm{l}$ Tris- $\mathrm{HCl}, 150 \mathrm{mmol} / \mathrm{l}$ $\mathrm{NaCl}, 10 \%$ DMSO, $4 \mathrm{mmol} / \mathrm{l}$ EDTA, $0.6 \%$ CHAPS) was used to

Table 1. RABV isolates from different reservoirs, year in which the samples were collected, species from which the samples were collected, and antigenic characterization of rabies virus isolates

\begin{tabular}{|c|c|c|c|c|}
\hline Sample & Year & Host & Antigenic variant ${ }^{\mathrm{a}}$ & Viral titer (FFU/ml) \\
\hline IP 5053 & 2010 & Canis familiaris & $\mathrm{V}-2$ & $1.38 \times 10^{3}$ \\
\hline IP 3629 & 2011 & Canis familiaris & $\mathrm{V}-2$ & $3.07 \times 10^{5}$ \\
\hline IP 6299 & 2013 & Canis familiaris & $\mathrm{V}-2$ & $9.70 \times 10^{3}$ \\
\hline IP 4005 & 2010 & Bos taurus & $\mathrm{V}-3$ & $3.07 \times 10^{5}$ \\
\hline IP 1684 & 2014 & Bos taurus & V-3 & $2.45 \times 10^{6}$ \\
\hline IP 1410 & 2014 & Desmodus rotundus & $\mathrm{V}-3$ & $1.73 \times 10^{5}$ \\
\hline IP 1770 & 2012 & Callithrix jacchus & $\mathrm{V}-\mathrm{M}^{\mathrm{b}}$ & $1.38 \times 10^{4}$ \\
\hline IP 6294 & 2013 & Callithrix jacchus & $\mathrm{V}-\mathrm{M}^{\mathrm{b}}$ & $3.07 \times 10^{5}$ \\
\hline IP 5451 & 2013 & Homo sapiens & $\mathrm{V}-\mathrm{M}^{\mathrm{b}}$ & $4.36 \times 10^{4}$ \\
\hline
\end{tabular}

aAntigenic variants as defined in the monoclonal antibody panel produced by the Centers for Disease Control and Prevention (CDC) Atlanta, USA;

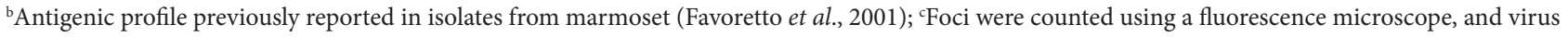
titers calculated in focus-forming units per milliliter (FFU/ml). 
solubilize the RABV glycoprotein as previously described (Ramya et al., 2013). The mixture was subsequently incubated for $30 \mathrm{~min}$ by end-to-end constant mixing at room temperature.

Protein separation. The proteins were extracted with radioimmunoprecipitation assay buffer (RIPA buffer) (Pierce, Meridian Rd, Rockford, IL, USA) containing complete protease inhibitor cocktails (Sigma, USA). The protein concentration was determined by BCA Protein Assay kit (Pierce - Thermo Fisher Scientific Inc.). A $20 \mu \mathrm{g}$ protein sample was separated on 10\% SDS-PAGE with 5\% stacking and stained with Coomassie Brilliant Blue.

In-gel tryptic digestion of proteins and mass spectrometry analysis. Protein bands were excised from the gel and reduced using $5 \mathrm{mmol} / \mathrm{l}$ dithiothreitol for $25 \mathrm{~min}$ at $56^{\circ} \mathrm{C}$, alkylated with $14 \mathrm{mmol} / \mathrm{l}$ iodoacetamide for $30 \mathrm{~min}$ at room temperature and digested with $20 \mathrm{ng}$ of trypsin gold (mass spectrometry grade, Promega) overnight at room temperature. Peptides were desalted on a C18 Sep-Pak Lite cartridge (Waters), eluted with $0.5 \%$ sodium deoxycholate and freeze-dried to dryness. Each sample was resuspended in $0.1 \%$ formic acid (solvent A) and analyzed in an EASY-nLC II nanoflow liquid chromatography (Thermo Scientific) prior to a nanoelectrospray into a LTQ-Orbitrap Velos mass spectrometer (Thermo Scientific). The analysis was performed over a 35 min gradient of
5-95\% in solvent B, composed of $0.1 \%$ formic acid in acetonitrile at a flow rate of $200 \mathrm{~nL} / \mathrm{min}$ using an in-house precolumn (ID $100 \mu \mathrm{m}$ x OD $360 \mu \mathrm{m}$ ) packed with $5 \mathrm{~cm}$ of $\mathrm{C}_{18} 10 \mu \mathrm{m}$ Jupier beads (Phenomenex) attached to an in house fritted-tip analytical column (ID $75 \mu \mathrm{m}$ x OD $360 \mu \mathrm{m}$ ) packed with $15 \mathrm{~cm}$ of $\mathrm{C}_{18} 5 \mu \mathrm{m}$ AQUA beads (Phenomenex). Data were acquired in the mass spectrometer operated in a data-dependent acquisition mode, where the top five precursor ions in each cycle were selected for fragmentation by collision-induced dissociation excluded for $70 \mathrm{~s}$, with a nanospray voltage set to $2.3 \mathrm{kV}$ and the source temperature set to $250^{\circ} \mathrm{C}$. Ion trap injection time was set to $100 \mathrm{~ms}$ and FT-MS injection time was set to $100 \mathrm{~ms}$ with a resolution of 30,000 across a m/z of 300-1800. MS/MS spectra were searched against a RABV protein (NCBI Taxonomy ID 11292) database using PEAKS Studio, version 7 software (Bioinformatics Solutions, Ontario, Canada). Mass tolerance for precursors was set to $10 \mathrm{ppm}$ and for MS/MS fragment ions to $0.5 \mathrm{Da}$. Trypsin was set for enzyme specificity with a maximum of 2 missed cleavages, with carbamidomethylation of cysteine included as fixed modification. The confidence interval for protein identification was set to $95 \%$ and only peptides with an individual ion score above the identity threshold were considered correctly identified. All spectra were additionally manually validated.

(a)

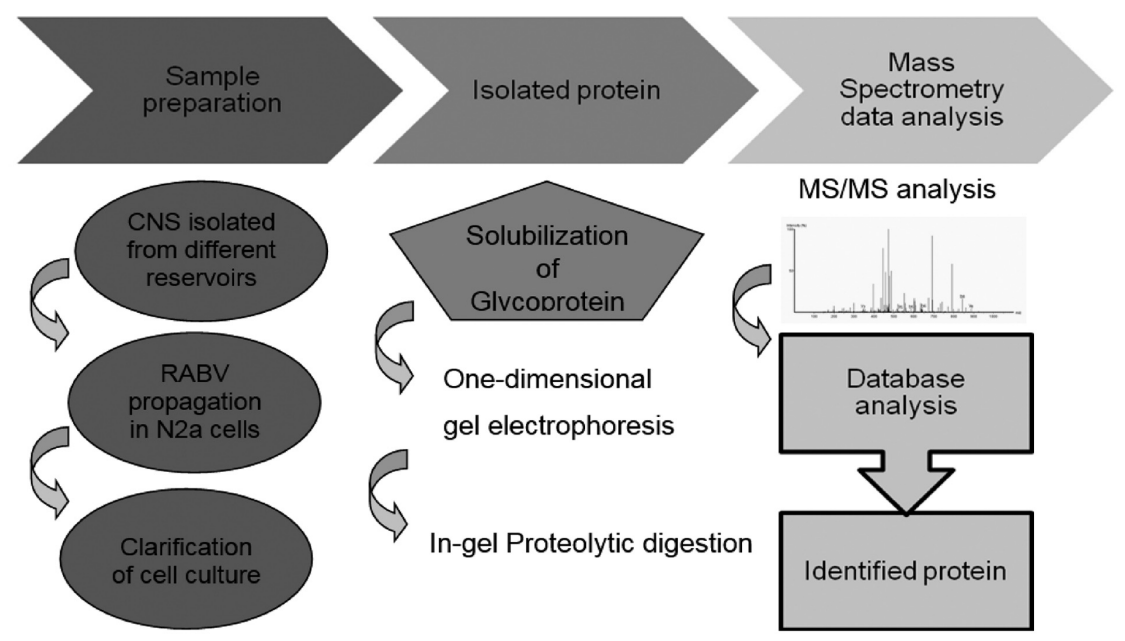

(b)

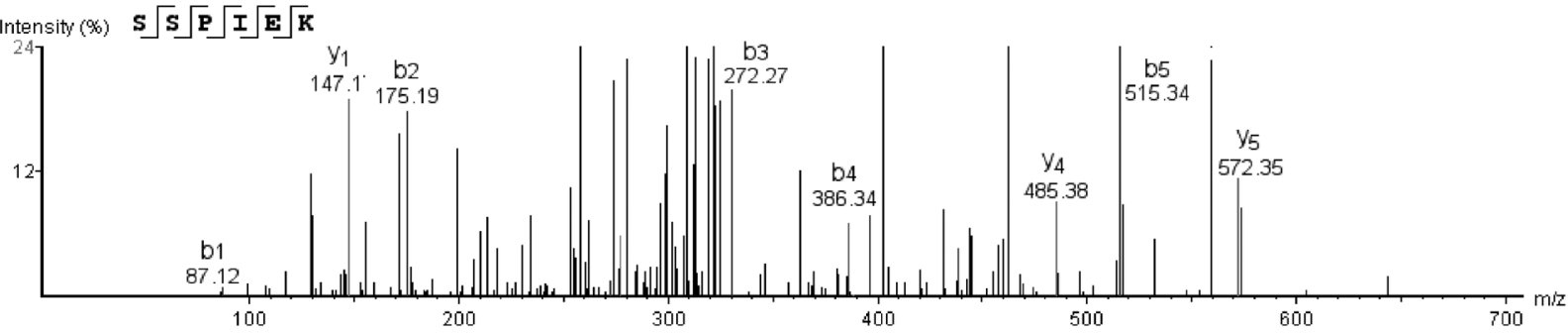

Fig. 1

Overview of the bioinformatic and experimental approaches employed for the identification and analysis of the RABV Mass spectrometry proteomics relies on the digestion with an enzyme, further analysis by mass spectrometry and bioinformatic tools helping in identification of proteins (a), the mass spectrum of the peptide SSPIEK of RABV L protein by ESI tandem mass spectrometry analysis (b). 


\section{Results}

To establish more stable condition for RABV identification for MS assay, firstly, we isolated the virus in N2a cells and then RABV from different Brazilian reservoir species were titered in the same cells (Table 1). We verified that virus isolation in N2a cell culture occurred in all samples, however, virus titer was higher in V-3 group. No significant differences in viral titer between samples sharing the same antigenic profile were observed (Table 1).

Subsequently, RABV proteins were extracted and solubilized from a clarified cell culture supernatant using CHAPSbuffered detergent solution. Proteins were separated by one-dimensional SDS PAGE, and two spots were manually excised from the gel (proteins above $50 \mathrm{kDa}$ and proteins below $50 \mathrm{kDa}$ ). After the proteolytic digestion using trypsin, samples were submitted to MS/MS analysis. All peptide spectra were searched against protein sequences for RABV downloaded from the UniProt database using PEAKS software for peptide identification and were manually validated (Fig. 1a). To exemplify, we presented a mass-spectra of the peptide SSPIEK of RABV large protein (Fig. 1b).

A total of 46 differentially expressed peptides were identified by ESI tandem mass spectrometry analysis of the samples from different reservoirs and from the CVS/31 strain. The resultant peptide number retrieved from the database search were 30, 8, 6, 1 and 1 for the L, N, G, P and $M$ proteins, respectively (Fig. 2a). Of these peptides, 11 were from CVS-31, 15 from V-2 group, 15 from V-3 group, and 24 from V-M group (Fig. $2 \mathrm{~b}$ and $3 \mathrm{c}$, Table 2), where the vast majority (30/46) of the RABV peptide sequences identified were localized in the L protein (Fig. 2a).

Due to the largest number of peptides from large protein detected, we evaluated quantity and similarity among matched peptides of large protein among samples of the same group, as well as the presence of identical peptides. As (a)

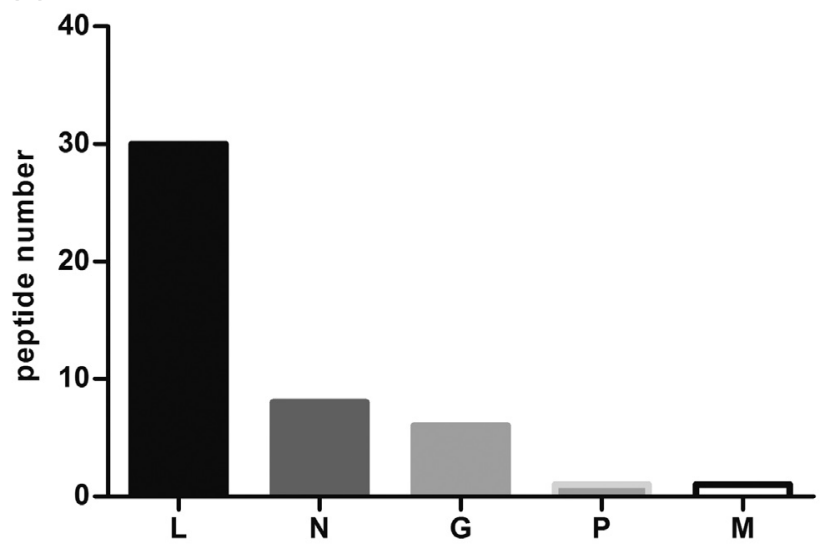

(b)

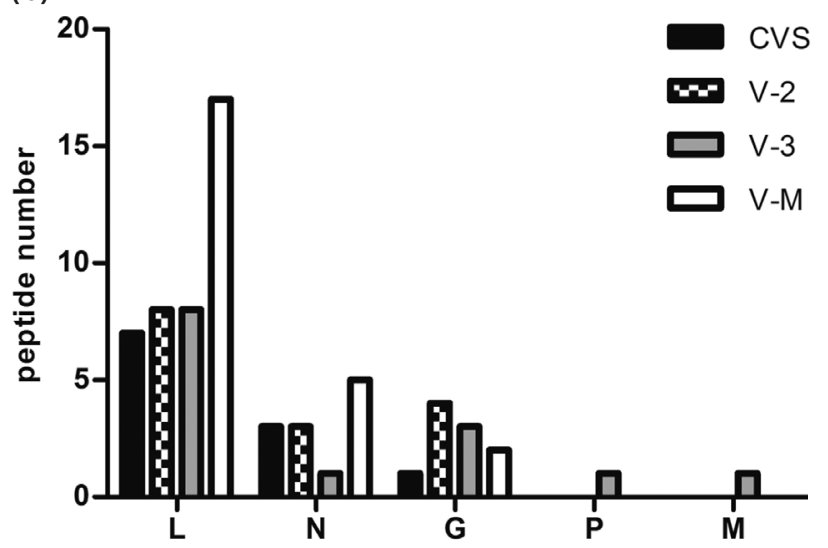

(c)

\section{Large protein}

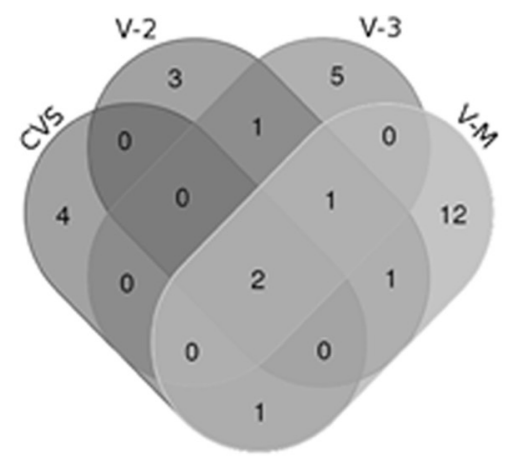

Nucleoprotein

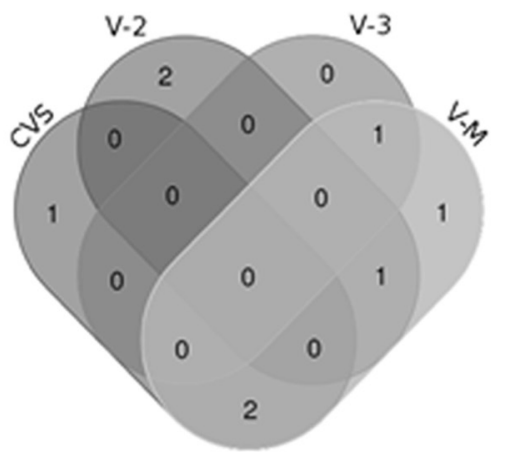

Fig. 2
Glycoprotein

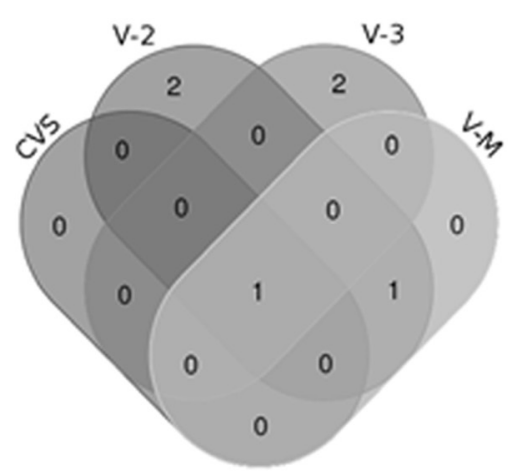

Total number of distinct peptide spectra matched for the RABV protein (a), total number of peptides from RABV proteins in different groups (b) and some of the subsets (c) obtained by MS in two independent experiments 
(a)

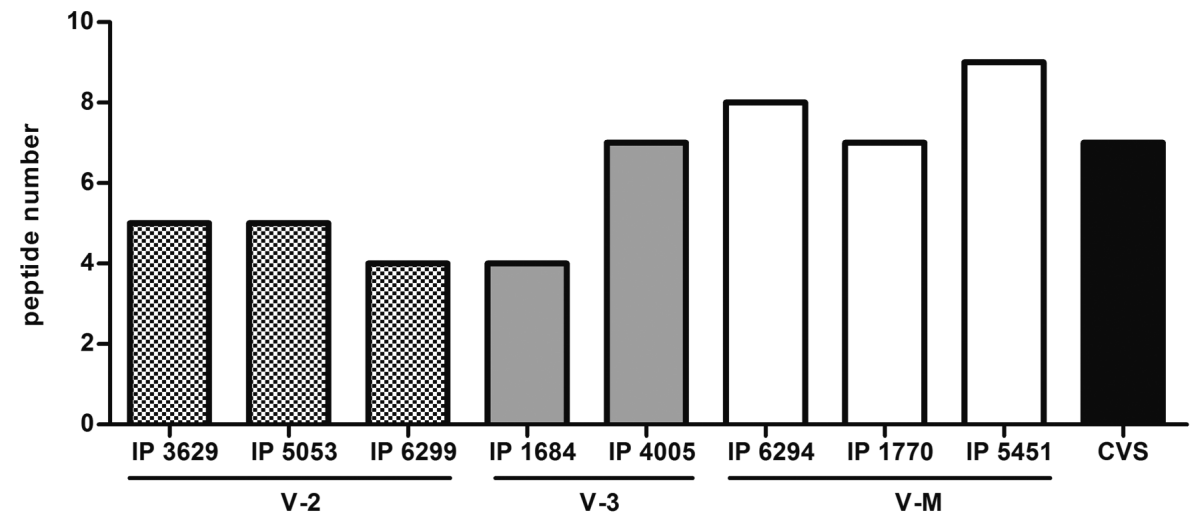

(b)
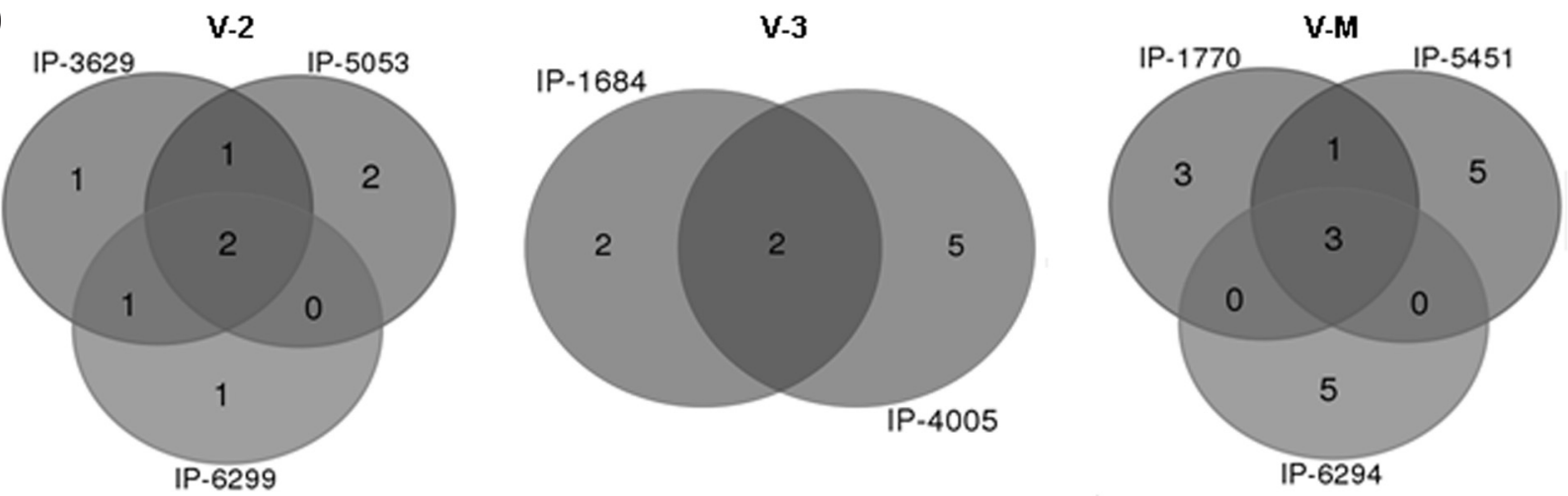

Fig. 3

Total number of peptides from RABV large proteins in different samples (a) and some of the subsets (b) obtained by MS in two independent experiments

shown in Fig. 3, a total of 8, 9 and 17 peptides were found in $\mathrm{V}-2, \mathrm{~V}-3$, and V-M groups, respectively. Among all identified peptides from large protein, we were able to identify at least two shared peptides in all samples (GDGSGGISR and SSPIEK) (Fig. 3, Table 2).

\section{Discussion}

The accurate and rapid identification of RABV is important to help public health measures, to initiate prophylaxis and early therapy. Antigen-detection is the most frequently used technique for RABV diagnosis. It involves detection of RABV $\mathrm{N}$ protein antigen in cell culture or in brain tissue by using immunofluorescence technique (OIE 2012; WHO, 2013). Gold standard assays have high sensitivity and specificity, however, the direct fluorescent antibody test and the rapid tissue culture infection test methods require an expensive fluorescence microscope, and mouse inoculation test requires live animals and is a time-consuming test (OIE 2012; Silva et al., 2013; WHO, 2013). In addition, the traditional tests in rabies diagnosis are not suitable for antemortem diagnosis and decomposed brains due to low sensibility (Madhusudana and Sukumaran, 2008). The direct rapid immunohistochemical test (dRIT) has been developed as an alternative to the fluorescent antibody test, and has the advantage of using light microscopy, even so it cannot be used in antemortem diagnosis (Madhusudana et al., 2012).

Nucleic acid amplification and detection techniques such as reverse transcriptase-PCR (RT-PCR) and real-time PCR are promising in samples for antemortem rabies diagnosis, however, a major drawback of these assays is the crosscontamination and reduced sensitivity in samples of decomposed tissue and in antemortem rabies diagnosis (Wacharapluesadee et al., 2011). Unlike these molecular methods that rely on the detection of only one protein, MS-based systems could overcome this drawback by ensuring that different peptides can be detected in the same test, thus increasing the sensitivity of the method. The high cost of the equipment and chemicals also limit a wide application of the genomic and proteomic tools, nevertheless these tools are vital due to their high sensitivity and quantitative accuracy. 
Table 2. RABV peptide sequences and their representations in different strains

\begin{tabular}{|c|c|c|c|c|c|}
\hline Protein name & UniProt ID & Protein Length (aa) & Group & Sample & Peptide \\
\hline \multirow[t]{52}{*}{$\mathrm{L}$} & D8VEC2 & 2127 & $\mathrm{~V}-2$ & 3629 & GDGSGGISR \\
\hline & & & & & SSPIEK \\
\hline & & & & & NKVFK \\
\hline & & & & & RAVLNMFPDSK \\
\hline & & & & & VNQLEGTFGPSAKR \\
\hline & & & & 5053 & GDGSGGISR \\
\hline & & & & & NKVFK \\
\hline & & & & & SSPIEK \\
\hline & & & & & TQTWPPK \\
\hline & & & & & TTRLIGSIK \\
\hline & & & & 6299 & GDGSGGISR \\
\hline & & & & & QIFEFPDVSK \\
\hline & & & & & RAVLNMFPDSK \\
\hline & & & & & SSPIEK \\
\hline & & & $\mathrm{V}-3$ & 1684 & FFALMSWNLR \\
\hline & & & & & GDGSGGISR \\
\hline & & & & & IIYLDPSLGGVSGMSLGR \\
\hline & & & & & SSPIEK \\
\hline & & & & 4005 & GDGSGGISR \\
\hline & & & & & DYLRGLAR \\
\hline & & & & & KVDLGSLK \\
\hline & & & & & RAVLNMFPDSK \\
\hline & & & & & SSPIEK \\
\hline & & & & & VNQLEGTFGPSAKR \\
\hline & & & & & VSGAVPQFQK \\
\hline & & & V-M & 1770 & GDGSGGISR \\
\hline & & & & & PMFIK \\
\hline & & & & & QMSSLMR \\
\hline & & & & & RAVLNMFPDSK \\
\hline & & & & & SSPIEK \\
\hline & & & & & TTRLIGSIK \\
\hline & & & & & VENSEFR \\
\hline & & & & 5451 & GDGSGGISR \\
\hline & & & & & EPSLR \\
\hline & & & & & QEAGNPDLGERTLESFTR \\
\hline & & & & & QMSSLMR \\
\hline & & & & & RAVLNMFPDSK \\
\hline & & & & & KESINWFINR \\
\hline & & & & & SNPYNEMIITLIDNDVESFLVHK \\
\hline & & & & & SSPIEK \\
\hline & & & & & TYGTMLVNPDYK \\
\hline & & & & 6294 & GDGSGGISR \\
\hline & & & & & GTPTVPNILR \\
\hline & & & & & QDLVR \\
\hline & & & & & QMSSLMR \\
\hline & & & & & SSPIEK \\
\hline & & & & & TDLAHFYSKSSPIEK \\
\hline & & & & & TLEESFYNSEIHGINR \\
\hline & & & & & WEKPSDLR \\
\hline & & & & CVS & GDGSGGISR \\
\hline & & & & & SSPIEK \\
\hline & & & & & WGFDK \\
\hline
\end{tabular}


Table 2 (continued)

\begin{tabular}{|c|c|c|c|c|c|}
\hline Protein name & UniProt ID & Protein Length (aa) & Group & Sample & Peptide \\
\hline & & & & & GGVSGMSLGR \\
\hline & & & & & EEGASKLGLIIK \\
\hline & & & & & SELVQR \\
\hline & & & & & QDLVR \\
\hline \multirow[t]{12}{*}{$\mathbf{N}$} & Q8JXF6 & 524 & $\mathrm{~V}-2$ & 3629 & FLAGTYDMFFSR \\
\hline & & & & & IMMNGGRLKR \\
\hline & & & & 5053 & SPEAVYTRIMMNGGR \\
\hline & & & $\mathrm{V}-3$ & 4005 & IVEHHTLMTTHK \\
\hline & & & V-M & 1770 & GDRITPNSLVEIK \\
\hline & & & & & IVEHHTLMTTHK \\
\hline & & & & & KPCITLGK \\
\hline & & & & 5451 & SPEAVYTRIMMNGGR \\
\hline & & & & & APDLNKAYK \\
\hline & & & & CVS & GDRITPNSLVEIK \\
\hline & & & & & KPCITLGK \\
\hline & & & & & TNIADR \\
\hline \multirow[t]{13}{*}{ G } & O92284 & 450 & $\mathrm{~V}-2$ & 3629 & LESIMTTK \\
\hline & & & & 5053 & LESIMTTK \\
\hline & & & & & QHMELLK \\
\hline & & & & & SLKGACRLK \\
\hline & & & & 6299 & KMAGDPR \\
\hline & & & & & LESIMTTK \\
\hline & & & V-3 & 4005 & QHMELLK \\
\hline & & & & & SFGGTGRNVSVTSQSGK \\
\hline & & & & & VFPGGK \\
\hline & & & $\mathrm{V}-\mathrm{M}$ & 1770 & QHMELLK \\
\hline & & & & & SLKGACRLK \\
\hline & & & & 6294 & QHMELLK \\
\hline & & & CVS & CVS & QHMELLK \\
\hline $\mathbf{P}$ & P22363 & 297 & $\mathrm{~V}-3$ & 4005 & AESFSKK \\
\hline $\mathbf{M}$ & P25223 & 202 & $\mathrm{~V}-3$ & 4005 & MIGLVK \\
\hline
\end{tabular}

The technical methods we used in the viral peptides identification by MS are not novel (Ying et al., 2004; Zeng et al., 2004; Benevento et al., 2014). Our challenge has been in adapting these elements to RABV and improving the efficiency of each step. Thus, this study shows a robust sample preparation method for mass spectrometry-based virus identification without prior purification, which is normally performed following laborious procedures. Here, performing only virus isolation is needed before samples can be prepared and analyzed by mass spectrometry for the detection of RABV. The virus isolation proved to be an effective strategy for RABV peptide identification by MS analysis. No correlation between the number of peptides and viral titer was found, thus the number of infectious virus particles is not important for RABV peptides identification. In order to remove sedimentation of suspended solids, and also for promoting a high clearance of protein impurities, such as membrane proteins, the cell supernatant clarification step is highly advantageous for recovery of proteins and peptides in culture supernatant.

Our data show that this assay allowed for a successful identification of five RABV proteins from different hosts based on detection of specific peptides. In this study, a total of 46 distinct peptides from RABV were found, in which the largest number of peptides were from the L protein, which was little described for rabies diagnosis (Dacheux et al., 2016). MS/MS spectra were searched against a fixed RABV protein (CVS-11), thus, with RABV L protein being the most conserved protein during lyssavirus evolution, these peptides are more likely to be found in the database. Hence, the different amount of peptides found from large protein could be related to well-conserved genomic regions in RABV (Bourhy et al., 1993). Moreover, the reason for the highest number of peptides being from the L protein could be the size of the protein, as it is at least four times larger than other RABV proteins. Thus, it has the greatest number of potential cleavage sites for trypsin. 
An important finding of the present study was the identification of two identical peptides sequences from $\mathrm{L}$ protein in all samples, which could be further used to develop a targeted proteomic method using SRM in the RABV. In addition to permitting a more rapid sample processing, as a consequence of eliminating the gel purification step, it allows direct identification of viruses in original samples. Thus, SRM-based targeted proteomics could be a potential new diagnostic tool in RABV diagnosis due to its capability to identify proteins of interest with high reproducibility and high accuracy.

Furthermore, the novelty and efficiency of the peptide identification by MS assay with a combination of high throughput antibody platforms could be a leading approach in the development of immunoassay for RABV detection.

The approach using both viral production and MS analysis showed that L protein can be extracted in an appropriate amount from infected cell cultures for MS diagnostic analysis, or may be used to identify candidate protein antigens for other methods such as immunoassay. The protein identification method will be a useful tool in future search.

Acknowledgements. We would like to thank Keila Iamamoto Nogi and Willian de Oliveira Fahl for testing the RABV virus samples. This work was supported by Instituto Pasteur/Brazil.

\section{References}

Benevento M, Di Palma S, Snijder J, Moyer CL, Reddy VS, Nemerow GR, Heck AJ (2014): Adenovirus composition, proteolysis, and disassembly studied by in-depth qualitative and quantitative proteomics. J. Biol. Chem. 18, 11421-11430. https://doi.org/10.1074/jbc.M113.537498

Bourhy H, Kissi B, Tordo N (1993): Virology Molecular diversity of the Lyssavirus genus. Virology 194, 70-81. https://doi. org/10.1006/viro.1993.1236

Castilho JC, Iamamoto K, Lima JYO, Scheffer KC, Carnieli JR P, Oliveira RN, Macedo CI, Achkar SM, Carrieri ML, Kotait I (2007): Padronização e aplicação da técnica de isolamento do vírus da raiva em células de neuroblastoma de camundongo (N2a). Bol. Epidemiol. Paulista 4, 12-18.

Dacheux L, Larrous F, Lavenir R, Lepelletier A, Faouzi A, Troupin C, Nourlil J, Buchy P, Bourhy H (2016): Dual Combined Real-Time Reverse Transcription Polymerase Chain Reaction Assay for the Diagnosis of Lyssavirus Infection. PLoS Negl. Trop. Dis. 10, e0004812. https://doi. org/10.1371/journal.pntd.0004812

Diaz AM, Papo S, Rodriguez A, Smith JS (1994): Antigenic analysis of rabies-virus isolates from Latin America and the Caribbean. Zentralbl. Veterinarmed B. 41, 153-160. https://doi. org/10.1111/j.1439-0450.1994.tb00219.x

Etessami R, Conzelmann KK, Fadai-Ghotbi B, Natelson B, Tsiang H, Ceccaldi PE (2000): Spread and pathogenic characteristics of a G-deficient rabies virus recombinant: an in vitro and in vivo study. J. Gen. Virol. 81, 2147-2153. https://doi. org/10.1099/0022-1317-81-9-2147

Favoretto SR, de Mattos CC, Morais NB, Alves Araújo FA, de Mattos CA (2001): Rabies in marmosets (Callithrix jacchus) from the State of Ceará, Brazil. Emerg. Infect. Dis. 7, 1062-1065. https://doi.org/10.3201/eid0706.010630

Gadre G, Satishchandra P, Mahadevan A, Suja MS, Madhusudana SN, Sundaram C, Shankar SK (2010): Rabies viral encephalitis: clinical determinants in diagnosis with special reference to paralytic form. J Neurol. Neurosurg. Psychiatry 81, 812-820. https://doi.org/10.1136/ innp.2009.185504

Hierholzer JC, Killington RA (1996): Suspension assay method. Virology Methods Manual, Academic, San Diego, pp. 39-40.

King A, Adams M, Carstens EB, Carstens EB (2012): Virus taxonomy: classification and nomenclature of viruses: Ninth Report of the International Committee on Taxonomy of Viruses. Tech. Rep., Elsevier Academic Press, San Diego.

Lange V, Picotti P, Domon B, Aebersold R (2008): Selected reaction monitoring for quantitative proteomics: a tutorial. Mol. Syst. Biol. 4, 222. https://doi.org/10.1038/msb.2008.61

Le Mercier P, Jacob Y, Tordo N (1997): The complete Mokola virus genome sequence: structure of the RNA-dependent RNA polymerase. J. Gen. Virol. 78,1571-1576. https://doi. org/10.1099/0022-1317-78-7-1571

Madhusudana SN, Sukumaran SM (2008): Antemortem diagnosis and prevention of human rabies. Ann. Indian Acad. Neurol. 11, 3-12. https://doi.org/10.4103/0972-2327.40219

Madhusudana SN, Subha S, Thankappan U, Ashwin YB (2012): Evaluation of a direct rapid immunohistochemical test (dRIT) for rapid diagnosis of rabies in animals and humans. Virol. Sin. 27, 299-302. https://doi.org/10.1007/ s12250-012-3265-6

Mehta S, Sreenivasamurthy S, Banerjee S, Mukherjee S, Prasad K, Chowdhary A (2016): Pathway Analysis of Proteomics Profiles in Rabies Infection: Towards Future Biomarkers? OMICS 20, 97-109. https://doi.org/10.1089/ omi.2015.0137

World Organisation for Animal Health (2012): Manual of diagnostic tests and vaccines for terrestrial animals. Paris: OIE 7th ed. Accessed 24 June 2016.

Orciari LA, Niezgoda M, Hanlon CA, Shaddock JH, Sanderlin DW, Yager PA, Rupprecht CE (2001): Rapid clearance of SAG-2 rabies virus from dogs after oral vaccination. Vaccine 19, 4511-4518. https://doi.org/10.1016/S0264410X(01)00186-4

Ramya R, Mohana Subramanian B, Sivakumar V, Senthilkumar RL, Sambasiva Rao KR, Srinivasan VA (2011): Expression and solubilization of insect cell-based rabies virus glycoprotein and assessment of its immunogenicity and protective efficacy in mice. Clin. Vaccine Immunol. 18, 1673-1679. https://doi.org/10.1128/CVI.05258-11

Rupprecht CE, Hanlon CA, Hemachudha T (2002): Rabies reexamined. Lancet Infect. Dis. 2, 327-343. https://doi. org/10.1016/S1473-3099(02)00287-6 
Silva SR, Katz IS, Mori E, Carnieli P Jr, Vieira LF, Batista HB, Chaves LB, Scheffer KC (2013): Biotechnology advances: a perspective on the diagnosis and research of Rabies Virus. Biologicals 41, 217-223. https://doi.org/10.1016/j. biologicals.2013.04.002

Thanomsridetchai N, Singhto N, Tepsumethanon V, Shuangshoti S, Wacharapluesadee S, Sinchaikul S, Chen ST, Hemachudha T, Thongboonkerd V (2011): Comprehensive proteome analysis of hippocampus, brainstem, and spinal cord from paralytic and furious dogs naturally infected with rabies. J. Proteome Res. 10, 4911e24. https://doi.org/10.1021/ pr200276u

Tian D, Luo Z, Zhou M (2015): Critical Role of K1685 and K1829 in the Large Protein of Rabies Virus in Viral Pathogenicity and Immune Evasion. J. Virol. 90, 232-244. https://doi. org/10.1128/JVI.02050-15

Tollis M, Dietzschold B, Volia CB (1991): Immunization of monkeys with rabies ribonucleoprotein (RNP) confers protective immunity against rabies. Vaccine $9,134-136$. https://doi. org/10.1016/0264-410X(91)90270-G

Venugopal AK, Ghantasala SS, Selvan LD, Mahadevan A, Renuse S, Kumar P, Pawar H, Sahasrabhuddhe NA, Suja MS, Ramachandra YL, Prasad TS, Madhusudhana SN, Hc H, Chaerkady R, Satishchandra P, Pandey A, Shankar SK (2013): Quantitative proteomics for identifying biomarkers for Rabies. Clin. Proteomics 10, 3. https://doi. org/10.1186/1559-0275-10-3

Wacharapluesadee S, Phumesin P, Supavonwong P, Khawplod P, Intarut N, Hemachudha TJ (2011): Comparative detection of rabies RNA by NASBA, real-time PCR and conventional PCR. Virol. Methods 175, 278-282. https://doi. org/10.1016/j.jviromet.2011.05.007

World Health Organization (2013): WHO expert consultation on rabies (second report). Geneva, Switzerland: WHO. Accessed 24 June 2016.

Wunner WH, Larson JK, Dietzschold B (1988): The molecular biology of rabies viruses. Rev. Infect. Dis. 10 (Suppl. _4.S7), S771-S784. https://doi.org/10.1093/clinids/10. supplement $4 . s 771$

Ying W, Hao Y, Zhang Y, Peng W, Qin E, Cai Y, Wei K, Wang J, Chang G, Sun W, Dai S, Li X, Zhu Y, Li J, Wu S, Guo L, Dai J, Wang J, Wan P, Chen T, Du C, Li D, Wan J, Kuai X, Li W, Shi R, Wei H, Cao C, Yu M, Liu H, Dong F, Wang D, Zhang X, Qian X, Zhu Q, He F (2004): Proteomic analysis on structural proteins of Severe Acute Respiratory Syndrome coronavirus. Proteomics 4, 492-504. https:// doi.org/10.1002/pmic.200300676

Yousaf MZ, Qasim M, Zia S, Khan Mu, Ashfaq UA, Khan S (2012): Rabies molecular virology, diagnosis, prevention and treatment. Virol. J. 9, 50. https://doi.org/10.1186/1743$\underline{422 X-9-50}$

Zeng R, Ruan HQ, Jiang XS, Zhou H, Shi L, Zhang L, Sheng QH, Tu Q, Xia QC, Wu JR (2004): Proteomic analysis of SARS associated coronavirus using two-dimensional liquid chromatography mass spectrometry and one-dimensional sodium dodecyl sulfate-polyacrylamide gel electrophoresis followed by mass spectroemtric analysis. J. Proteome Res. 3, 549-555. https://doi.org/10.1021/pr034111j 